\title{
Detection of Toxoplasma gondii antibodies in horses in Mosul, Iraq
}

\author{
M.N. Alshahery and R.S. Mansour \\ Department of Microbiology, College of Veterinary Medicine, University of Mosul, Mosul, Iraq
}

\begin{abstract}
This study was aimed to verify the presence of Toxoplasma gondii antibodies in equine sera in Mosul city, Iraq. Seventy nine samples of sera were examined (70 female and 9 male) by latex agglutination test (LAT) and 2-Mercaptoethanol test (2ME). Results showed that anti-bodies to $T$. gondii using LAT were detected in $72.2 \%$ ( $71.4 \%$ female and $77.8 \%$ male) whereas $57 \%$ (57.1\% female and $55.6 \%$ male) of infected horses were detected by 2 -ME.
\end{abstract}

Keywords: Toxoplasma gondii; Antibodies; Latex agglutination; Equine.

Available online at http://www.vetmedmosul.org/ijvs

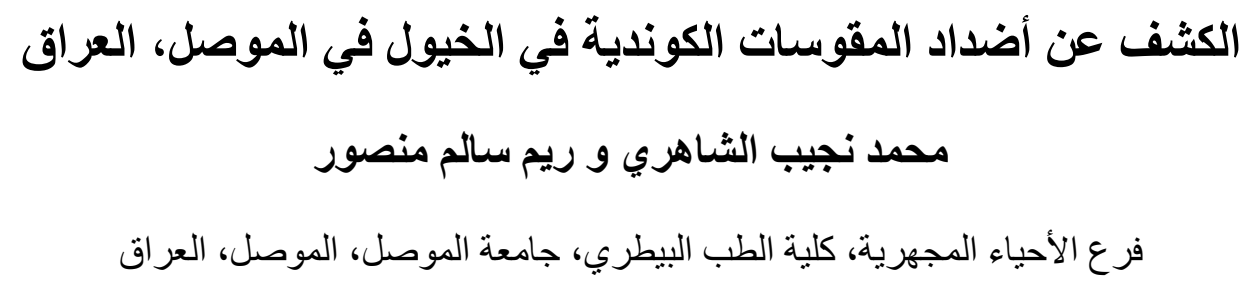

الخلاصة

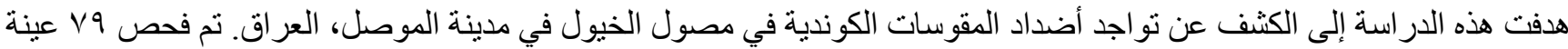

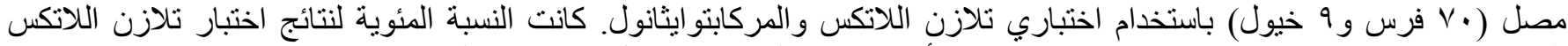

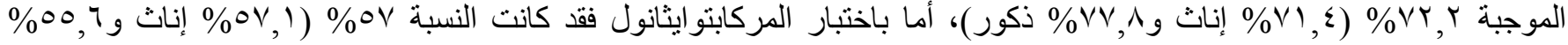

ذكور).

\section{Introduction}

Toxoplasma gondii is an intracellular protozoan parasite capable of infecting most tissues in mammals and various tissues in avian species (1). Therefore, it is considered as a significant agent with regard to aspects of animal production as it can provoke abortion among different animal species of economic importance, as well as to public health due to its high prevalence in human infection (2). Both domestic and wild felids are the only known definitive hosts of $T$. gondii in which the sexual cycle can take place (3). Hence cats play a central role in the epidemiology of $T$. gondii, constituting the only known source of environmental contamination with the infective oocyst stage (4).

Horses are most commonly infected by ingestion of sporulated oocysts found in feces of infected cats (5). $T$. gondii was isolated in Australia from the diaphragm of one out of four horses (6). In USA, it was isolated from different tissues and organs (heart, diaphragm, spinal cord, brain, tongue, skeletal muscles, liver and kidney) in 4 out of 9 ponies experimentally fed infective $T$. gondii oocyst by mouse inoculation and feeding of cats (7).

T. gondii infection stimulates both the humoral immune response as antibody production, which includes IgM and IgG in addition to cell mediated immunity (CMI). CMI response is essential for host control on intracellular infection like T. gondii (8).

Although toxoplasmosis generally causes subclinical infections in horses, it may also lead to symptoms including progressive neurological findings such as ataxia, paralysis, blindness, fever, retinal degeneration and severe encephalomyelitis (1,9-11). A case of an infection in eye of aborted foals in UK has been reported (12). Horses generally display low susceptibility to the disease. However young animals and animals with immunosuppression (sick, pregnant animals) are more susceptible to toxoplasmosis (13). Since T. gondii infections generally display sub- 
clinical course in horses, serological techniques for the detection of specific antibodies produced in the body against the parasite have great diagnostic value $(14,15)$. Many recent studies in Mosul city in Iraq, deals with toxoplasmosis in rabbits (16), cattle (17), turkeys (18), sheep (19), buffaloes (20) and donkeys (21). Up to our knowledge, there are no known investigations about the prevalence of infection in horses, therefore our study was aimed to verify the presence of $T$. gondii antibodies in equine sera in Mosul city.

\section{Materials and methods}

\section{Samples}

Blood samples were collected between 2010-2011 from clinically healthy 79 horses of race breed ( 70 female and 9 male) aged 2-10 years, with a history of abortion.

Five $\mathrm{ml}$ of blood were individually harvested by jugular vein punctured into non-heparinized tubes to obtain sera which were separated by centrifugation at $3000 \mathrm{rpm}$ for 15 minutes. The collected sera were stored at $-20^{\circ} \mathrm{C}$ until analysis (22).

\section{Serological Examination}

Latex Agglutination test (LAT): The titer of Toxoplasma antibodies values in serum were estimated using commercial kits (Biokit, Spain SA, toxo-cell-latex), according to the procedure outlined by the manufacturer, which detecting total Toxoplasma antibodies of IgG and $\operatorname{IgM}$.

2-ME test: This test was performed for seropositive samples in paragraph (a) to detect Toxoplasma antibodies of IgM to confirm active toxoplasmosis (23).

\section{Results}

Among 79 horses tested for the presence of $T$. gondii antibodies, 57 were found to be seropositive using latex test, (50 female and 7 male), the LAT detect the total immunoglobulin IgG and IgM (Table 1).

Table (1): Percentage of T. gondii reactors using LAT.

\begin{tabular}{|c|c|c|c|c|}
\hline \multirow{2}{*}{$\begin{array}{l}\text { No. } \\
\text { of examined } \\
\text { sera }\end{array}$} & \multicolumn{2}{|c|}{ Positive reactors } & \multirow{2}{*}{$\begin{array}{l}\text { Negative } \\
\text { reactors } \\
\text { No. }\end{array}$} & \multirow[b]{2}{*}{$\%$} \\
\hline & No. & $\%$ & & \\
\hline Total 79 & 57 & 72.2 & 22 & 27.8 \\
\hline Female 70 & 50 & 71.4 & 20 & 28.6 \\
\hline Male 9 & 7 & 77.8 & 2 & 22.2 \\
\hline
\end{tabular}

Results were also showed that 45 horses were positive by using 2-ME (40 female and 5 male), (Table 2 ).
Table (2): Percentage of $T$. gondii antibodies reactors using 2-ME.

\begin{tabular}{llrlc}
\hline $\begin{array}{l}\text { No. } \\
\text { of examined }\end{array}$ & \multicolumn{2}{c}{ Positive } & \multicolumn{2}{c}{ Negative } \\
reactors & \multicolumn{3}{c}{ reactors } \\
sera & No. & $\%$ & No. & $\%$ \\
\hline Total 79 & 45 & 57 & 34 & 43 \\
Female 70 & 40 & 57.1 & 30 & 42.9 \\
Male 9 & 5 & 55.6 & 4 & 44.4 \\
\hline
\end{tabular}

The distribution of different titers in seropositive animals by using LAT was variable, the titers were ranging between 1:20 to 1:640 (Table 3).

Table (3): Distribution of antibody titers by LAT according to genders.

\begin{tabular}{|c|c|c|c|c|c|}
\hline \multirow[t]{2}{*}{ Titer } & \multirow{2}{*}{$\begin{array}{l}\text { No. of total } \\
\text { infected } \\
\text { animals } 45\end{array}$} & \multicolumn{2}{|c|}{$\begin{array}{c}\text { Male } 7 \text { of } \\
\text { total } 9\end{array}$} & \multirow{2}{*}{\multicolumn{2}{|c|}{$\begin{array}{c}\text { Female } 50 \\
\text { of total } 70 \\
\text { No. } \%\end{array}$}} \\
\hline & & No. & $\%$ & & \\
\hline $1: 20$ & 3 & 1 & 14.3 & 2 & 4 \\
\hline $1: 40$ & 3 & - & - & 3 & 6 \\
\hline $1: 80$ & 13 & 2 & 28.6 & 11 & 22 \\
\hline $1: 160$ & 25 & 4 & 57.1 & 21 & 42 \\
\hline $1: 320$ & 12 & - & - & 12 & 24 \\
\hline $1: 640$ & 1 & - & - & & \\
\hline
\end{tabular}

While the positive results in horses by using 2-ME have different titers ranging between 1:20 to 1:160 (Table 4).

Table (4): Distribution of antibody titers by 2-ME according to genders.

\begin{tabular}{|c|c|c|c|c|c|}
\hline \multirow[t]{2}{*}{ Titer } & \multirow{2}{*}{$\begin{array}{l}\text { No. of total } \\
\text { infected } \\
\text { animals } 45\end{array}$} & \multicolumn{2}{|c|}{$\begin{array}{c}\text { Male } 5 \text { of } \\
\text { total } 9\end{array}$} & \multicolumn{2}{|c|}{$\begin{array}{c}\text { Female } 40 \\
\text { of total } 70\end{array}$} \\
\hline & & No. & $\%$ & $\mathrm{No}$ & $\%$ \\
\hline $1: 20$ & 7 & & & 7 & 17.5 \\
\hline $1: 40$ & 14 & 2 & 40 & 12 & 30 \\
\hline $1: 80$ & 16 & 5 & 60 & 13 & 32.5 \\
\hline $1: 160$ & 8 & & & 8 & 20 \\
\hline
\end{tabular}

\section{Discussion}

The prevalence of equine Toxoplasma in different regions appear to be associated to environmental factors such as humidity, temperature and height (24). In general, prevalence is greater in warm and humid areas than in arid and semi-arid regions. Other epidemiological factors must be considered, such as the feline population infected, age, and type of animal management (25).

The seroprevalence rates variation to $T$. gondii. in horses between our results and those previously reported may be due to the serologic test used; initial serum dilution; 
the virulence of $T$. gondii strains, the immune status, age and management of investigated animals in different localities (9).

The prevalence of $T$. gondii infection in horses at the different localities in the world is extremely variable. It was $57 \%$ in the present study, which is more than that reported in other parts of the world $(215,25-31)$. The reasons for these discrepancies may be explained by spatial, temporal and many other factors determining the prevalence of toxoplasmosis in animals as well as possible differences among laboratories and testing procedure and number of animals tested (15). It is conceivable that high seroprevalence rates for toxoplasmosis in horses in this study is a result of environmental contamination with $T$. gondii oocysts. However, horses examined here were bred in farm and villages; this increases the risk of exposure to animal of felidae family and feces of cats.

Protection to $T$. gondii turned out to be complex involving innate and specific immunity. In the 1940s humoral antibodies were found to kill extracellular but not intracellular tachyzoites (32). Protective immunity was found to be mediated largely by immune lymph cells (8). Mapping of $T$. gondii genes was achieved recently and undoubtedly will help in search for better antigens for diagnosis and protection, and mechanism of disease (33). It is concluded that horses in Mosul city are highly infected with toxoplasmosis, and this may affect breeding of race horses.

\section{References}

1. Altintas K. Toxoplasma gondii infections of animals in Turkey. Türkiye Parazitol Derg. 1996; 20:479-487.

2. Tenter AM, Heckeroth AR, Weiss LM. Toxoplasma gondii : from animals to humans. Internat. J Parasitol. 2000; 30(12-13):1217-1258.

3. Frenkel JK, Dubey JP and Miller NL. Toxoplasma gondii in cats: fecal stages identified as coccidian oocysts. Science. 1970; 167:893-896.

4. Miller NL, Frenkel JK and Dubey JP. Oral infections with Toxoplasma cysts and oocysts in felines, other mammals, and in birds. J Parasitol. 1972; 58:928-937.

5. Aganga AO, Kwanashie GG and Belino ED. Toxoplasma antibodies in polo horses of Nigeria. Internat. J Zoonos. 1983; 10(2): 155-158.

6. Munday BL. The epidemiology for toxoplasmosis with particular reference to the Tasmanian environment. M.Sc. Thesis, Melbourne University, Australia.1970.

7. Al-Khalidi NW, Weisbrode SE and Dubey JP. Pathogenicity of Toxoplasma gondii oocysts to ponies. Am J Vet Res. 1980; 41: 15491551.

8. Suzuki Y, Orellana MA, Schreiber RD and Remington JS. Interferon gamma, the major mediator of resistance against Toxoplasma gondii Science.1988; 240:516-518.

9. Dubey JP and Beattia CP. Toxoplasmosis of animals and man. CRC Press. Boca Raton, FL.USA. 1988: 1-220.

10. Soulsby EJL. Helminths, Arthropods and Protozoa of Domesticated animals. $7^{\text {th }}$ ed. Bailliere Tindal, London. 1986.

11. Tunner CB and Savva D. Evidence of T. gondii in an equine placenta. Vet Rec. 1990; 127:96.
12. Tunner CB and Savva D. Detection of T. gondii in equine eyes. Vet Rec 1991; 129-128.

13. Tunner CB and Savva D. Transplacental infection of a foal with $T$. gondii. Vet Rec. 1992; 131: 179-180.

14. Macruz R, Lenci O and Ishizuka MM. Toxoplasmose em equinos PSI: Estudo serologico. Rev Fac Med Vet Zootec Univ Sao. Paulo. 1975; 12: $2777-2778$.

15. Güçlü Z, Karaer Z, Babür C and Kiliç S. Investigation of Toxoplasma gondii antibodies in sport horses bred in Ankara province. Türkiye Parazitoloji Dergisi. 2007; 31(4): 264-267.

16. Aghwan SS, Al-Taee AF and Suliman EG. Detection of Toxoplasma gondii infection in domestic rabbits by using multiple techniques. Iraqi J Vet Sci. 2010; 24(2):65-69.

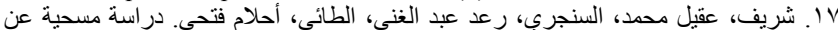

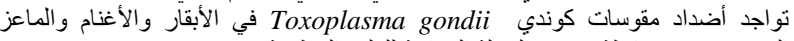

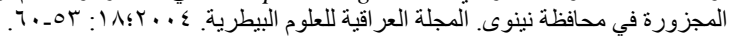

18. Butty ET. Diagnostic study of Toxoplasma gondii in turkey (Meleagris gallopavo) in some regions in Ninevah governorate, Iraq. Iraqi J of Vet. Sci.2009; Vol. 23, Supplement I, (57-62) Proceedings of the $5^{\text {th }}$ Scientific Conference. College Vet Med University of Mosul, Mosul, Iraq.

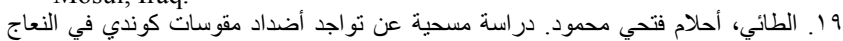

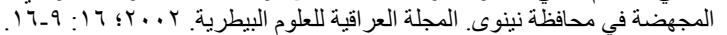

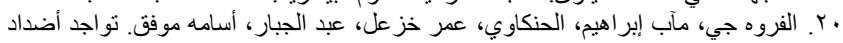

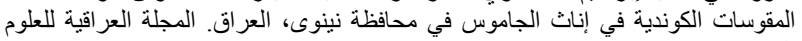

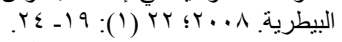

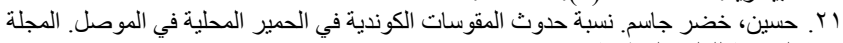

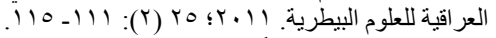

22. Coles EH. Veterinary Clinical Pathology. $2^{\text {nd }}$ ed. Philadelphia W.B. Saunders company.USA. 1974; pp.47.

23. Desmonts G and Remington JS. Direct agglutination test for diagnosis of Toxoplasma infection: methods for increasing sensitivity and specificity. J Clin Microbiol. 1980;11:562-568.

24. Gazenta GS. et al. Frequencia de anticorpos anti-Toxoplasma gondii em soros de equinos no Estado do Rio de janeiro, Brazil. Revista Brasileira de Parasitologia Veterinaria.1997; 6(2):87-91.

25. Chhabra MB, Gupta GL, Gautam OP. Toxoplasma seroprevalence in animals in northern India. Int J Zoonoses.1985; 12:136-142.

26. Dubey JP., Kerber CE and Granstrom DE. Serologic prevalence of Sarcocystis neurona, Toxoplasma gondii and $N$. caninum in horses in Brazil. J Am Vet Med Assoc. 1999; 215: 970-972.

27. Dubey JP, Venturini MC, Ventirini L, McKinney J, and Pecoraro M. Prevalence of antibodies to Sarcocystis nurona, Toxoplasma gondii and Neospora caninum in horses from Argentina. Vet Parasitol. 1999; 86: 59-62.

28. Uggla A, Mattson S, Juntti N. Prevalence of antibodies to Toxoplasma gondii in cats, dogs and horses in Sweden. Acta Vet Scand.1990; 31: 219-222.

29. Van Knapen F, Franchimont JH, Van Der Lugt G. Prevalence of antibodies to Toxoplasma in farm animals in the Netherlands and its implication for meat inspection. Vet Q. 1982; 4:101-105.

30. Ghazy AA, Shaapan RM and Abdel-Rahman EH. Comparative serological diagnosis of toxoplasmosis in horses using locally isolated Toxoplasma gondii. Vet. Parasitol.2007; 145: 31-36.

31. Weilland G and Dalkckow W. Toxoplasma infectionen bei Haustieren in der Turkei (Serologische Untersuchungen im Sabin-Feldman test). Berl Munich Tierarztl Wschr.1970; 83: 65-68.

32. Dubey JP. The history of Toxoplasma gondii- the first 100 years. J Eukaryot Microbiol. 2008; 55(6). p. 467-475.

33. Khan A, Taylor S, Mackey Su C, Boyle J, Glover RD, Tang K, Paulsen IT, Berriman M, Boothrooyd JC, Pfefferkorn ER, Dubey JR., Ajioka JW, Ross DS, Wootton JC, and Sibley LD. Comparative genome map and recombination parameters derived from three archetypal lineages of Toxoplasma gondii. Nucleic acids Res.2005;33: 2980-2992. 